\title{
Graphic organizers to empower the teaching-learning process of grammar tenses in higher education
} (c) (1)(2)(2)

Organizadores gráficos para empoderar la enseñanza-aprendizaje de los tiempos gramaticales en la educación superior

Jazmín Marisol Medina Rea. ${ }^{1}$

Recibido: 07-05-2021 / Revisado: 18-05-2021 /Aceptado: 11-06-2021/ Publicado: 05-07-2021

\begin{abstract}
.
DOI: https://doi.org/10.33262/concienciadigital.v4i3.1764

The English language is a mandatory subject in elementary, secondary, and higher education in Ecuador. To become proficient, a broad knowledge of grammar is needed because it is considered the backbone of a language. This research aims to implement graphic organizers in the teaching-learning process of grammar tenses. This inquiry took place at a university of Riobamba with a target population of 62 A2 level students. A quasi-experimental research, was carried out with 31 students that were the experimental group and the same number of students as the control group. A pre-test was applied to both groups to evaluate their grammar skills. After that, both groups were given a posttest to determine if the graphic organizers implemented made any improvement on the students' performance regarding grammar tenses. The post-test results demonstrated that the competence of the experimental group students has been enhanced after implementing graphic organizers. Furthermore, students were able to clear up their ideas and to establish better relationships between graphical and cognitive demands. Hence, the research findings showed that graphic organizers will contribute positively to master grammar patterns.
\end{abstract}

Keywords: Graphic organizers, teaching, learning, grammar

\footnotetext{
${ }^{1}$ Pontificia Universidad Católica del Ecuador, Maestría en Pedagogía del Inglés, Ambato, Ecuador, email jazmin.medina@pucesa.edu.ec
} 


\section{Resumen.}

El idioma inglés es una asignatura obligatoria en la educación primaria, secundaria y superior en Ecuador. Para llegar a ser competente, se necesita un amplio conocimiento de la gramática porque se considera la columna vertebral de un idioma. Esta investigación tiene como objetivo implementar organizadores gráficos en el proceso de enseñanzaaprendizaje de los tiempos gramaticales. Dicha investigación se llevó a cabo en una universidad de Riobamba con una población objetivo de 62 estudiantes de nivel A2. Se realizó una investigación cuasi-experimental, con 31 estudiantes que fueron el grupo experimental y el mismo número de estudiantes como el grupo de control. Se aplicó una prueba previa a ambos grupos para evaluar sus habilidades gramaticales. Posteriormente, a ambos grupos se les realizó una prueba posterior para determinar si los organizadores gráficos implementados mejoraron el desempeño de los estudiantes con respecto a los tiempos gramaticales. Los resultados de la prueba posterior demostraron que la competencia de los estudiantes del grupo experimental ha mejorado después de implementar organizadores gráficos. Además, los estudiantes pudieron aclarar sus ideas y establecer mejores relaciones entre las demandas gráficas y cognitivas. Por lo tanto, los hallazgos de la investigación mostraron que los organizadores gráficos contribuirán positivamente a dominar los patrones gramaticales.

Palabras claves: Organizadores gráficos, enseñanza, aprendizaje, gramática.

\section{Introducción.}

According to a recent study on English level proficiency, Ecuador has been ranked 81/100 countries with 46.57 and it is located in the 19/19 position in Latin America. These findings are supported by the EF EPI (2019) which demonstrated that Ecuador has a very low level of language proficiency.

In Ecuador, the English language has not been seen as a priority because we are a Spanishspeaking country, nonetheless, the advancement of the technological world has required to introduce a new curriculum in which new policies have been implemented regarding the teaching-learning process of English. Teachers are required to have a B2 level of proficiency to be able to teach in all educational institutions as well as in higher education. Despite all the new policies implemented, there are still weaknesses concerning the heart of a foreign language. It is vital to cite Foppoli (2018) and his crucial comparison: "without knowledge of grammar, in the same way as a train cannot move without railways, people won't be able to communicate their ideas without a good mastery of grammar".

Universities consider English as a requirement for students to graduate. Riobamba universities are characterized by welcoming students from different provinces and therefore different economic strata. Often, students are fluent when speaking although 
they do not show a good level of accuracy and coherence. It might happen due to the lack of grammar knowledge. According to Garrido \& Rosado (2012), missformation is the use of the wrong form or morpheme or structure. Thus, grammar is considered essential in any skill domain to avoid misunderstandings. In addition, Mart (2013) claims that "to establish effective communication, learners need grammar skills". Grammar needs to be seen and taught as the fifth skill of a language for students to master any language.

The majority of higher education students struggle in master tenses (Ali, 2015). Even though grammar has been given a special role in early levels, learners are not conscious of rules and patterns (Rahman \& Ali, 2015). Often, students are fluent when speaking however they do not show a good level of accuracy and coherence. Therefore, the problem arises because of the lack of grammar knowledge they experiment at higher levels. In fact, various causes are addressing the poor performance of it. Traditional teachers supply difficult rules and constraints with several amounts of information that is hard to concise, process, and understand (Dahbi, 2014). Moreover, the grammatical misunderstandings and the wrong use of patterns make learners produce errors in morpheme and sentence structure (Garrido \& Rosado, 2012). From the learners' perspective, grammar is seen as a monster that constantly presses them to follow each rule and pattern carefully, if it is not so, they will be punished with low scores. Thus, they feel overwhelmed and argue that grammar knowledge is not necessary to learn in English since they believe it is bored and not interesting (Mammadova, 2019).

\section{Graphic Organizers}

According to (Ellis \& Howard, 2005) graphic organizers are pictorial devices that illustrate information in different ways of representations. Often, those representations include a set of shapes, lines, and boxes to generate images with structured information. Similarly, Drapeau (1999) as cited in Dahbi (2014) adds "a graphic organizer is a visual and graphic display that depicts the relationships between facts, terms, and or ideas within a learning task." (p. 37). Therefore, the use of graphic organizers helps students consolidate a vast amount of information into comprehensible language within minimum time (Ciascai, 2009).

Ciascai (2009) presents some functions to spell the efficiency of graphic organizers to teach as well as to learn. He states the following: "clarifying knowledge and reasoning", "strengthening the learning process", "integrationing the new knowledge in the prior knowledge system", and "identificating the conceptual errors (and missconceptions [sic])" (par. 1). As we can see, visual maps can empower and promote students' reasoning and innovative teaching strategies.

Graphic organizers as a teaching-learning tool helps students to express knowledge, concepts, thoughts, and their associations (Ghanizadeh, Al-Hoorie, \& Jahedizadeh, 2020). Most of the time, students are given too much semantic information to process and understand. One reason may be that teachers provide disorganized information which is demanding to comprehend. Based on that assumption, learners argue that grammar is uninterested and not necessary to learn in English. For that reason, Ratnakar (2017) 
highlights the importance of graphic organizers because students can "convert and compress a lot of seemingly disjointed information into a structured, simple-to-read, graphic display. The resulting visual display conveys complex information in a simpleto-understand manner.” (p. 4531)

Among several tools to teach grammar, graphic organizers are flexible and differ from traditional grammar teaching. They are used for different purposes because they can be adapted for any activity teachers or students require to be used. Undoubtedly, students will be able to keep information organized, recognize relationships regarding concepts, ideas, and examples (Vargas \& Zuñiga, 2018). Just as (Krasnic, 2011) cited in (Kansizoğlu, 2017) assumes the brain represents all that difficult information into graphical organization devices, so they can comprehend, find solutions, make decisions, and meet the expected results.

To implement graphic organizers is a process that requires teachers and students' effort and collaboration. Hence, to be successful when constructing these visual representations, it is necessary to cite clear guidelines. According to Vargas \& Zuñiga (2018), the role of the teacher is guiding learners by giving instructions of highlighting the most relevant ideas, the input has to be noticeable through the use of graphic organizers, to establish connections between previous and new knowledge, and to take advantage of the text in order to make it understandable. Thus, teachers must make comprehensible for learners on how to build effective graphic maps in order to represent lots of information into core ideas.

Learners can encounter many benefits when using graphic organizers also known as visual maps. Thinking and creativity are joined together to create meaningful representations of vast amounts of text (Kansizoğlu, 2017). Additionally, (Delrose, 2011) emphasizes that information is presented in a fluid simple way which helps to overcome cognitive load by categorizing all information sources in just one place. In effect, Dahbi (2014) in his study reports that graphic organizers help students to learn longer and more efficiently. Therefore, students can remember more main ideas when they are represented visually than in a simple text (Salazar \& Galora, 2017).

"The use of this tool brings excitement and enthusiasm toward learning" Dahbi (2014). Although learners can choose and use many shapes and ways of representing graphic organizers, there are rules to consider. Regarding this assumption, (Delrose, 2011) suggests some important aspects to be considered when creating these tools. Firstly, students have to be conscious about coherence. Secondly, the lack of familiarity with the format of organizers resulting in student's frustration. Finally, incoherent sets of graphic organizers could cause confusion and disorganization (Baxendell, 2003; Ellis \& Howard, 2005) cited in (Delrose, 2011). Thus, a systematic implementation of these pictorial devices must be considered inside and outside the classroom.

To sum up, Mercuri (2011) states some clear purposes for teachers and students implementation of graphic organizers. First, graphic organizers support the teaching and learning of grammar because they are powerful and manageable tools. Second, graphic organizers help the students to sum up, organize, categorize, and meet 
meaning from texts. Third, graphic organizers enhance the comprehension of grammar by assessing students' prior knowledge and promoting written and oral participation. Fourth, teachers play an important role to assess ongoing learning and modeling instruction to encounter students' needs. In essence, graphic organizers empower the teaching learning process of grammar tenses.

\section{Grammar Component}

"A legendary monger scares learners of English". This is how (Baron, 1982, p. 226) cited in (Al-Mekhlafi \& Nagaratnam, 2011) calls grammar. When students listen to the word "grammar" or when someone corrects them a piece of writing or any speech, they feel uncomfortable. They think they are making mistakes, so they feel ashamed. Most of the time students do not participate actively in class when they are asked to because they do not manage even basic grammatical patterns.

Grammar is the backbone of a language, it is a system that contains rules, restrictions, and patterns. Ratnakar (2017) states that each language has a cycle, it is said; it has evolved through the years. There is a controversial question regarding this skill, is the learning of grammar necessary to master a language? The answer would probably be no. Just as children learn a language by making sounds, then they produce words and phrases. They do not know the word grammar. However, when they want to learn a second language, the answer is yes because they need to know grammatical patterns to be fluent and accurate.

It is important to emphasize some challenges teachers and learners of English have to encompass in higher education. Mastering a language is not easy without the knowledge of grammar. In his study, Kelly (2018) presents some mastering lexical aspects and the focus on academic writing issues. He states some issues that have to do with the current situation in Ecuador. He argues that teachers are balky to implement some strategies on teaching grammar; the traditional teaching is comfortable for teachers and learners as well.

In addition, Al-Mekhlafi \& Nagaratnam (2011) points out grammar as a "linguistic straitjacket" (p. 71). They assume that this skill must give students freedom and motivation to be able to communicate their ideas accurately. Most students have had different teachers and of course they have acquired different schemata regarding structures, lexical words, adjectives, adverbs, and so on. However, Chen \& Jones (2012) argue that learners need enough exposure to the grammar otherwise, they will not be able to learn effectively. Thus, it must be seen as a skill that let learners discover rather than keep the knowledge down.

There are diverse ideas regarding grammar and its teaching and learning process. According to what students say, grammar is not motivational. Furthermore, Jean \& Simard (2011) point out a triangulation among teachers, learners, and grammar instruction. This shape displays they are working almost on the same rail. Despite this, students often accept grammar as essential. However, it is crucial to highlight the idea 
that grammar instruction does not grab students' attention because it is considered not funny. If learning is fun, students attempt to practice it and they remember the grammatical patterns.

Grammar instruction is necessary when learning a new language. It would be better if this skill is learned into an organized and precise way. The use of graphic organizers contributes to the learning process of English. The idea to be taken is that grammar is an important skill to learn in a second language faster and effectively (Varade, 2017). Besides, there is a big range of graphic organizers that could help to support mastering tenses. Therefore, this study explains how the two variables joint together to generate a well-done product.

\section{Metodologia.}

The study followed a quasi-experimental design which is well recognized by researchers around the world due to its adaptability for every methodological field. According to Thyer (2012), the objective of this design is to compare the results of the group of study (the one that receives a treatment) to one or more groups that are given or not an alternative treatment. Similarly, in this research, two groups were chosen to be evaluated and compared; the one called "the experimental group" received a treatment to improve its manageability of the grammatical patterns, and the control group was given a conventional grammar teaching.

In addition, this study is considered descriptive because the dependent and independent variables were depicted in the theoretical framework. Nassaji 2015 argues "The goal of descriptive research is to describe a phenomenon and its characteristics" (p. 129). Because of that, the variables stated a clear view of the factors that influenced this study. The author concludes that this kind of research focuses essentially on what the phenomenon is rather than on some other factors such as why or how. It means that the definitions help the readers to have a deep knowledge of the study direction.

This inquiry took place at a university with a target population of 62 A2 level students of different provinces because this university welcomes them from all around the country. The participants were males and females distributed in two levels of 31 students by the university administration. Level " $\mathrm{K}$ " was the control group and those in " $\mathrm{B}$ " were assigned to be the experimental group. In the beginning, a pre-test containing 20 questions about different grammatical patterns was applied to both groups to evaluate their grammar skills.

Once the treatment started, the experimental group was taught some grammatical patterns through the use of a series of graphic organizers. Consequently, they learned how to build them and also established relationships between their cognition and the graphical representations they had over texts. Thus, the students reacted positively to the pictorial devices shown with the grammar subjected to their study. On the other hand, the control group didn't receive treatment because they were given explanations complemented with examples and worksheets, too. Both processes were carried out two days a week for two 
months. After applying the intervention plan, the groups were given a post-test to state if the graphic organizers implemented made any improvement on the students' performance regarding grammar tenses.

The quantitative method was finally used to analyze the numerical data by applying statistical procedures to get the results. According to Apuke (2017), the data to be considered quantitative must be based on accurate information of responses, interviews, participants, and so on. Those data are validated through the data collection instruments such as surveys to test the hypothesis of the research study.

\section{Resultados.}

Table 1. Pretest, control group

\begin{tabular}{|c|c|c|c|c|c|c|c|c|c|c|c|c|c|c|c|c|c|c|c|c|c|}
\hline Students & P1 & $\mathrm{P} 2$ & P3 & P4 & P5 & P6 & P7 & P8 & P9 & P10 & P11 & P12 & P13 & P14 & P15 & P16 & P17 & P18 & P19 & P20 & Average \\
\hline S 1 & 0 & 1 & 1 & 1 & 1 & 1 & 1 & 1 & 1 & 1 & 0 & 1 & 1 & 1 & 0 & 0 & 1 & 0 & 0 & 0 & 13 \\
\hline S 2 & 1 & 1 & 1 & 0 & 1 & 1 & 1 & 1 & 1 & 0 & 0 & 1 & 1 & 1 & 0 & 1 & 1 & 0 & 0 & 0 & 13 \\
\hline S 3 & 0 & 1 & 1 & 1 & 0 & 1 & 1 & 0 & 0 & 1 & 0 & 0 & 1 & 1 & 1 & 1 & 1 & 1 & 1 & 0 & 13 \\
\hline S 4 & 1 & 1 & 1 & 1 & 1 & 1 & 1 & 1 & 1 & 1 & 0 & 1 & 1 & 0 & 0 & 1 & 0 & 1 & 1 & 0 & 15 \\
\hline S 5 & 0 & 1 & 1 & 0 & 1 & 1 & 1 & 1 & 1 & 1 & 1 & 1 & 1 & 1 & 0 & 1 & 0 & 1 & 1 & 1 & 16 \\
\hline S 6 & 1 & 1 & 0 & 1 & 1 & 1 & 1 & 1 & 1 & 1 & 1 & 1 & 1 & 1 & 1 & 1 & 1 & 1 & 1 & 0 & 18 \\
\hline S 7 & 1 & 0 & 1 & 0 & 1 & 1 & 1 & 1 & 1 & 1 & 0 & 1 & 1 & 1 & 0 & 1 & 1 & 0 & 1 & 0 & 14 \\
\hline S 8 & 0 & 1 & 1 & 0 & 1 & 0 & 1 & 0 & 1 & 1 & 1 & 0 & 0 & 1 & 0 & 0 & 1 & 0 & 0 & 0 & 9 \\
\hline S 9 & 0 & 0 & 1 & 0 & 1 & 0 & 1 & 0 & 0 & 0 & 0 & 0 & 1 & 0 & 1 & 1 & 0 & 0 & 1 & 0 & 7 \\
\hline S 10 & 1 & 1 & 1 & 1 & 1 & 1 & 1 & 1 & 1 & 1 & 0 & 0 & 1 & 0 & 0 & 1 & 0 & 1 & 1 & 0 & 14 \\
\hline S 11 & 1 & 1 & 1 & 1 & 0 & 1 & 1 & 1 & 1 & 1 & 0 & 1 & 1 & 0 & 1 & 0 & 1 & 1 & 1 & 0 & 15 \\
\hline S 12 & 1 & 1 & 0 & 1 & 1 & 1 & 1 & 1 & 1 & 1 & 1 & 1 & 1 & 0 & 0 & 1 & 0 & 0 & 0 & 0 & 13 \\
\hline S 13 & 1 & 1 & 0 & 1 & 1 & 1 & 1 & 0 & 0 & 1 & 0 & 0 & 0 & 0 & 0 & 1 & 0 & 0 & 1 & 0 & 9 \\
\hline S 14 & 1 & 1 & 1 & 1 & 1 & 1 & 1 & 1 & 1 & 0 & 0 & 0 & 1 & 1 & 0 & 1 & 1 & 0 & 0 & 0 & 13 \\
\hline S 15 & 1 & 0 & 1 & 0 & 0 & 1 & 0 & 1 & 1 & 1 & 0 & 0 & 0 & 0 & 0 & 1 & 0 & 0 & 0 & 0 & 7 \\
\hline S 16 & 1 & 1 & 1 & 1 & 1 & 1 & 1 & 1 & 1 & 1 & 0 & 1 & 1 & 1 & 1 & 0 & 1 & 1 & 0 & 1 & 17 \\
\hline S 17 & 1 & 1 & 1 & 0 & 1 & 1 & 1 & 1 & 1 & 0 & 1 & 1 & 1 & 1 & 1 & 1 & 0 & 1 & 1 & 1 & 17 \\
\hline S 18 & 0 & 1 & 0 & 0 & 1 & 0 & 1 & 1 & 1 & 0 & 1 & 1 & 1 & 0 & 1 & 1 & 0 & 1 & 0 & 1 & 12 \\
\hline S 19 & 0 & 1 & 1 & 0 & 1 & 0 & 1 & 1 & 1 & 1 & 0 & 1 & 1 & 0 & 1 & 1 & 1 & 1 & 1 & 0 & 14 \\
\hline S 20 & 1 & 1 & 0 & 0 & 1 & 1 & 0 & 1 & 1 & 1 & 0 & 1 & 1 & 0 & 1 & 1 & 0 & 1 & 1 & 0 & 13 \\
\hline S 21 & 0 & 1 & 1 & 0 & 1 & 1 & 1 & 1 & 0 & 1 & 1 & 1 & 0 & 1 & 1 & 1 & 1 & 1 & 1 & 0 & 15 \\
\hline S 22 & 1 & 1 & 0 & 0 & 1 & 1 & 1 & 1 & 1 & 1 & 0 & 1 & 1 & 0 & 1 & 1 & 0 & 0 & 1 & 0 & 13 \\
\hline S 23 & 0 & 0 & 1 & 0 & 0 & 0 & 1 & 1 & 1 & 1 & 0 & 0 & 0 & 0 & 0 & 1 & 0 & 1 & 1 & 0 & 8 \\
\hline S 24 & 0 & 0 & 1 & 0 & 0 & 0 & 1 & 1 & 1 & 1 & 1 & 1 & 1 & 0 & 1 & 1 & 0 & 1 & 1 & 1 & 13 \\
\hline S 25 & 0 & 1 & 0 & 0 & 0 & 1 & 1 & 1 & 1 & 0 & 1 & 0 & 0 & 1 & 1 & 1 & 1 & 1 & 1 & 1 & 13 \\
\hline S 26 & 1 & 1 & 1 & 0 & 1 & 1 & 0 & 1 & 1 & 1 & 1 & 1 & 1 & 0 & 1 & 1 & 0 & 0 & 0 & 0 & 13 \\
\hline S 27 & 0 & 0 & 1 & 0 & 1 & 0 & 1 & 1 & 1 & 1 & 1 & 1 & 1 & 1 & 1 & 1 & 0 & 0 & 1 & 0 & 13 \\
\hline S 28 & 1 & 1 & 1 & 0 & 1 & 1 & 1 & 1 & 1 & 1 & 1 & 1 & 1 & 1 & 1 & 1 & 1 & 0 & 1 & 1 & 18 \\
\hline S 29 & 1 & 1 & 1 & 0 & 1 & 1 & 1 & 1 & 1 & 1 & 1 & 1 & 1 & 1 & 1 & 1 & 1 & 1 & 1 & 1 & 19 \\
\hline S 30 & 0 & 1 & 1 & 1 & 1 & 1 & 1 & 1 & 1 & 0 & 0 & 0 & 0 & 0 & 0 & 0 & 0 & 1 & 0 & 0 & 9 \\
\hline$\overline{\mathrm{x}}$ & 0,57 & 0,80 & 0,76 & 0,37 & 0,72 & 0,77 & 0,90 & 0,87 & 0,87 & 0,77 & 0,43 & 0,67 & 0,77 & 0,50 & 0,57 & 0,83 & 0,47 & 0,57 & 0,67 & 0,27 & 13,11 \\
\hline
\end{tabular}

Note: The pretest average of the control group is 13, 11 over 20.

Source: Pretest control group

Developed by: The author. 
Table 2. Pretest, experimental group

\begin{tabular}{|c|c|c|c|c|c|c|c|c|c|c|c|c|c|c|c|c|c|c|c|c|c|c|}
\hline Students & P1 & $\mathrm{P} 2$ & P3 & $\mathrm{P} 4$ & P5 & P6 & & P7 & P8 & P9 & P10 & P11 & P12 & P13 & P14 & P15 & P16 & P17 & P18 & P19 & $\mathrm{P} 20$ & Average \\
\hline S 1 & 1 & 1 & 1 & & & & 1 & 1 & 1 & 1 & 1 & 1 & 1 & 1 & 0 & 0 & 1 & 1 & 0 & 1 & 0 & 15 \\
\hline S 2 & 1 & 1 & 1 & & & & 1 & 1 & 1 & 1 & 1 & 1 & 1 & 1 & 0 & 1 & 1 & 1 & 1 & 1 & 0 & 18 \\
\hline S 3 & 1 & 1 & 1 & & & & 0 & 1 & 1 & 1 & 1 & 0 & 0 & 1 & 0 & 1 & 1 & 1 & 1 & 1 & 0 & 14 \\
\hline $\mathrm{S} 4$ & 1 & 1 & 1 & & & & 0 & 1 & 1 & 1 & 0 & 0 & 1 & 1 & 1 & 1 & 1 & 1 & 1 & 1 & 0 & 15 \\
\hline S 5 & 0 & 0 & 1 & & & & 1 & 0 & 1 & 1 & 1 & 1 & 0 & 1 & 0 & 0 & 1 & 0 & 1 & 1 & 0 & 11 \\
\hline S 6 & 0 & 1 & 1 & & 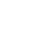 & & 1 & 1 & 1 & 1 & 1 & 0 & 0 & 0 & 1 & 0 & 1 & 0 & 1 & 0 & 0 & 10 \\
\hline S 7 & 1 & 1 & 1 & & & & 1 & 1 & 1 & 1 & 1 & 1 & 1 & 1 & 1 & 1 & 1 & 0 & 1 & 1 & 0 & 18 \\
\hline S 8 & 1 & 1 & 1 & & & & 1 & 1 & 1 & 1 & 0 & 0 & 1 & 1 & 0 & 0 & 1 & 1 & 1 & 0 & 0 & 13 \\
\hline S 9 & 0 & 1 & c & & & & 1 & 1 & 0 & 0 & 0 & 0 & 0 & 0 & 0 & 1 & 1 & 1 & 0 & 1 & 0 & 7 \\
\hline S 10 & 0 & 1 & 1 & & & & 0 & 0 & 1 & 1 & 1 & 0 & 0 & 1 & 0 & 0 & 0 & 1 & 1 & 1 & 0 & 10 \\
\hline S 11 & 1 & 1 & 1 & & & & 0 & 1 & 1 & 1 & 1 & 0 & 1 & 1 & 0 & 0 & 1 & 0 & 0 & 1 & 0 & 12 \\
\hline S 12 & 0 & 1 & 1 & & & & 0 & 1 & 1 & 1 & 1 & 0 & 1 & 0 & 1 & 1 & 0 & 1 & 0 & 1 & 1 & 13 \\
\hline S 13 & 1 & 0 & 1 & & & & 0 & 1 & 1 & 1 & 1 & 0 & 1 & 1 & 0 & 1 & 1 & 1 & 1 & 0 & 1 & 14 \\
\hline S 14 & 0 & 1 & 1 & & & & 1 & 1 & 1 & 1 & 0 & 0 & 0 & 1 & 1 & 0 & 0 & 0 & 1 & 1 & 0 & 10 \\
\hline S 15 & 1 & 1 & 1 & & & & 1 & 1 & 1 & 1 & 1 & 1 & 1 & 1 & 0 & 1 & 1 & 0 & 0 & 1 & 0 & 16 \\
\hline S 16 & 1 & 1 & c & & & & 0 & 1 & 1 & 0 & 1 & 1 & 0 & 1 & 0 & 0 & 1 & 0 & 1 & 0 & 0 & 10 \\
\hline S 17 & 1 & 1 & 1 & & & & 1 & 0 & 1 & 0 & 0 & 1 & 1 & 1 & 1 & 0 & 1 & 0 & 1 & 1 & 1 & 14 \\
\hline S 18 & 0 & 1 & 1 & & & & 1 & 0 & 1 & 1 & 1 & 0 & 1 & 1 & 0 & 1 & 0 & 0 & 1 & 0 & 0 & 10 \\
\hline S 19 & 1 & 1 & 1 & & & & 1 & 0 & 1 & 1 & 1 & 1 & 1 & 1 & 1 & 1 & 1 & 0 & 1 & 1 & 0 & 16 \\
\hline S 20 & 1 & 1 & 1 & & & & 1 & 1 & 1 & 1 & 1 & 1 & 1 & 1 & 1 & 1 & 1 & 1 & 0 & 1 & 1 & 19 \\
\hline S 21 & 1 & 1 & 1 & & & & 0 & 1 & 1 & 1 & 1 & 1 & 1 & 1 & 0 & 0 & 1 & 0 & 1 & 1 & 0 & 14 \\
\hline S 22 & 1 & 1 & 1 & & & & 1 & 1 & 1 & 1 & 1 & 0 & 1 & 1 & 1 & 0 & 1 & 0 & 1 & 1 & 1 & 16 \\
\hline S 23 & 1 & 1 & 1 & & & & 1 & 0 & 1 & 0 & 1 & 1 & 1 & 1 & 1 & 1 & 1 & 1 & 1 & 1 & 1 & 18 \\
\hline S 24 & 0 & 1 & 1 & & & & 0 & 1 & 1 & 1 & 1 & 0 & 0 & 1 & 1 & 0 & 1 & 0 & 1 & 1 & 0 & 12 \\
\hline S 25 & 1 & 1 & 1 & & & & 1 & 1 & 1 & 1 & 1 & 1 & 0 & 1 & 1 & 1 & 1 & 1 & 1 & 0 & 0 & 16 \\
\hline S 26 & 0 & 1 & $c$ & & & & 0 & 1 & 1 & 0 & 0 & 0 & 0 & 1 & 1 & 0 & 1 & 0 & 1 & 0 & 1 & 9 \\
\hline S 27 & 1 & 1 & 1 & & & & 0 & 1 & 1 & 1 & 1 & 0 & 0 & 1 & 0 & 1 & 0 & 0 & 1 & 1 & 0 & 11 \\
\hline S 28 & 0 & 0 & 1 & & & & 0 & 1 & 1 & 1 & 0 & 1 & 1 & 1 & 1 & 0 & 1 & 1 & 1 & 1 & 0 & 13 \\
\hline S 29 & 0 & 1 & c & & & & 0 & 1 & 1 & 0 & 1 & 0 & 0 & 1 & 0 & 0 & 1 & 0 & 0 & 1 & 1 & 9 \\
\hline S 30 & 1 & 1 & 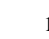 & & & & 1 & 1 & 1 & 1 & 1 & 0 & 1 & 1 & 1 & 1 & 0 & 1 & 0 & 0 & 0 & 14 \\
\hline
\end{tabular}

\begin{tabular}{lllllllllllllllllllll}
0,63 & 0,90 & 0,87 & 0,20 & 0,80 & 0,57 & 0,80 & 0,97 & 0,80 & 0,77 & 0,43 & 0,60 & 0,90 & 0,50 & 0,50 & 0,80 & 0,47 & 0,73 & 0,73 & 0,27 & 13,23 \\
\hline
\end{tabular} Note: The pretest average of the experimental group is 13,23 over 20.

Source: Pretest experimental group

Developed by: The author.

Table 3. Postest, control group

\begin{tabular}{lccccccccccccccccccccc} 
Students & P1 & P2 & P3 & P4 & P5 & P6 & P7 & P8 & P9 & P10 & P11 & P12 & P13 & P14 & P15 & P16 & P17 & P18 & P19 & P20 & Average \\
\hline S 1 & 0 & 1 & 0 & 1 & 0 & 1 & 0 & 0 & 0 & 0 & 0 & 1 & 1 & 1 & 0 & 0 & 0 & 1 & 1 & 1 & 9 \\
S 2 & 0 & 0 & 1 & 1 & 0 & 1 & 1 & 0 & 0 & 0 & 0 & 1 & 1 & 0 & 0 & 0 & 1 & 1 & 0 & 0 & 8 \\
S 3 & 0 & 0 & 1 & 1 & 1 & 0 & 0 & 0 & 1 & 0 & 1 & 0 & 1 & 0 & 0 & 1 & 0 & 1 & 0 & 0 & 8 \\
S 4 & 1 & 1 & 1 & 1 & 1 & 1 & 1 & 1 & 0 & 1 & 1 & 1 & 1 & 1 & 1 & 1 & 1 & 1 & 1 & 1 & 19 \\
S 5 & 1 & 0 & 0 & 1 & 0 & 0 & 0 & 1 & 1 & 0 & 0 & 0 & 0 & 1 & 0 & 0 & 0 & 0 & 0 & 0 & 5 \\
S 6 & 1 & 1 & 1 & 1 & 1 & 1 & 1 & 1 & 1 & 1 & 1 & 1 & 1 & 1 & 1 & 1 & 0 & 1 & 0 & 1 & 18 \\
S 7 & 1 & 0 & 1 & 0 & 1 & 0 & 0 & 1 & 1 & 1 & 1 & 0 & 0 & 0 & 1 & 1 & 0 & 0 & 0 & 1 & 10 \\
S 8 & 1 & 1 & 0 & 1 & 1 & 0 & 0 & 1 & 0 & 1 & 1 & 0 & 0 & 1 & 1 & 1 & 0 & 0 & 0 & 1 & 11 \\
S 9 & 1 & 1 & 0 & 1 & 1 & 0 & 0 & 0 & 1 & 1 & 0 & 0 & 0 & 0 & 0 & 1 & 0 & 1 & 1 & 1 & 10
\end{tabular}




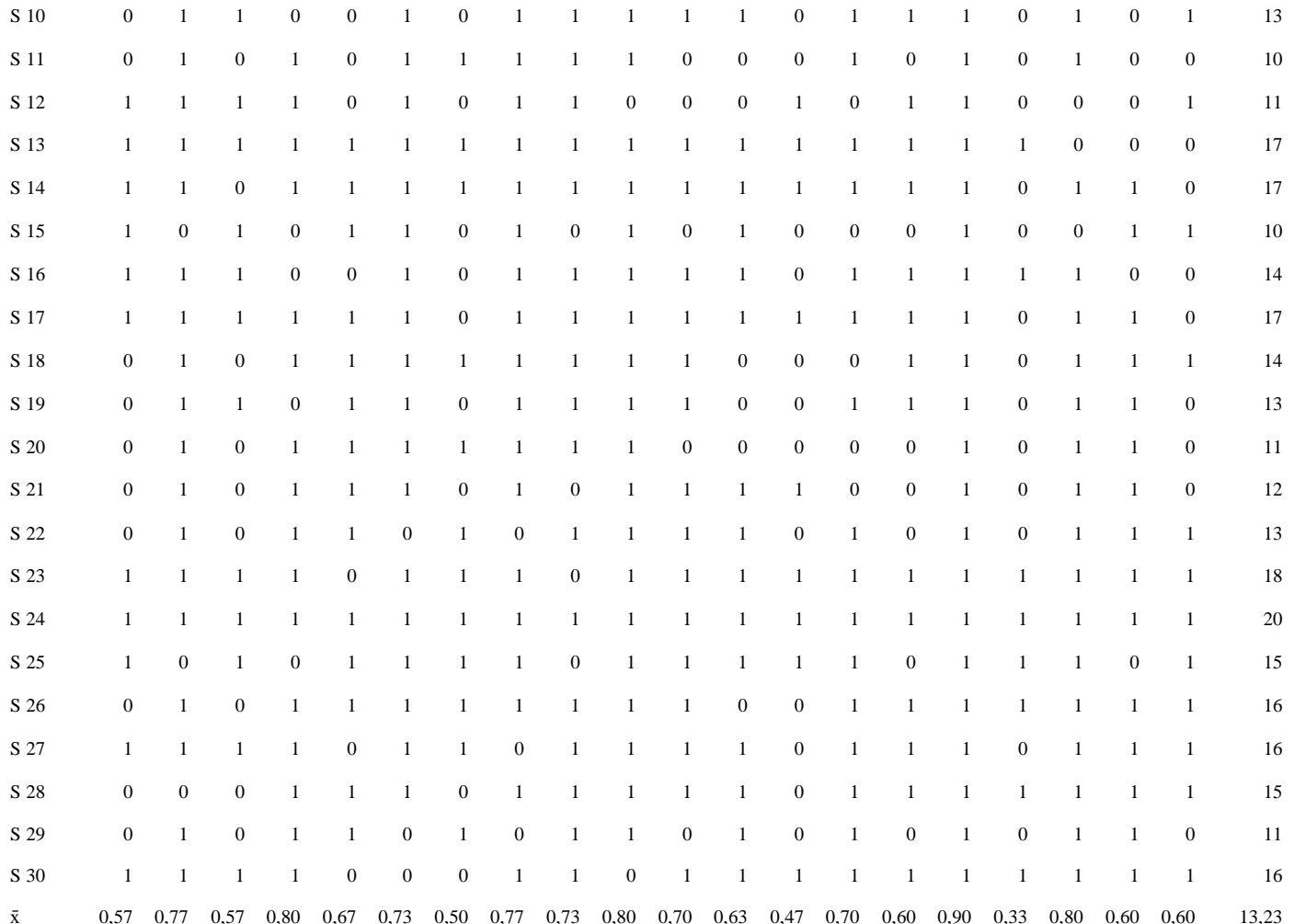

Note: The postest average of the control group is 13,23 over 20.

Source: Postest control group

Developed by: The author

Table 4. Postest, experimental group

\begin{tabular}{|c|c|c|c|c|c|c|c|c|c|c|c|c|c|c|c|c|c|c|c|c|c|}
\hline Students & P1 & $\mathrm{P} 2$ & $\mathrm{P} 3$ & $\mathrm{P} 4$ & P5 & P6 & $\mathrm{P} 7$ & P8 & P9 & $\mathrm{P} 10$ & P11 & $\mathrm{P} 12$ & $\mathrm{P} 13$ & $\mathrm{P} 14$ & $\mathrm{P} 15$ & P16 & P17 & P18 & P19 & $\mathrm{P} 20$ & Average \\
\hline S 1 & 1 & 1 & 1 & 1 & 1 & 1 & 1 & 0 & 1 & 1 & 1 & 0 & 1 & 1 & 0 & 1 & 1 & 1 & 1 & 0 & 16 \\
\hline S 2 & 1 & 0 & 1 & 1 & 1 & 0 & 0 & 0 & 1 & 1 & 0 & 0 & 1 & 1 & 0 & 0 & 0 & 1 & 0 & 1 & 10 \\
\hline S 3 & 1 & 1 & 0 & 1 & 1 & 0 & 0 & 0 & 1 & 1 & 1 & 0 & 0 & 1 & 1 & 1 & 1 & 1 & 1 & 0 & 13 \\
\hline S 4 & 0 & 0 & 0 & 1 & 1 & 1 & 1 & 0 & 1 & 1 & 1 & 0 & 1 & 1 & 0 & 1 & 1 & 1 & 1 & 1 & 14 \\
\hline S 5 & 1 & 1 & 0 & 1 & 0 & 1 & 1 & 0 & 1 & 0 & 0 & 1 & 1 & 1 & 0 & 1 & 0 & 0 & 1 & 1 & 12 \\
\hline S 6 & 0 & 0 & 0 & 1 & 0 & 0 & 0 & 1 & 1 & 0 & 0 & 0 & 0 & 1 & 0 & 0 & 1 & 0 & 1 & 0 & 6 \\
\hline S 7 & 1 & 1 & 1 & 1 & 1 & 1 & 1 & 1 & 1 & 1 & 1 & 1 & 1 & 1 & 1 & 1 & 1 & 1 & 1 & 1 & 20 \\
\hline S 8 & 1 & 1 & 1 & 1 & 1 & 1 & 1 & 1 & 1 & 1 & 1 & 1 & 1 & 1 & 1 & 1 & 1 & 1 & 1 & 1 & 20 \\
\hline S 9 & 1 & 1 & 1 & 1 & 1 & 0 & 0 & 1 & 1 & 1 & 0 & 1 & 1 & 1 & 0 & 1 & 1 & 1 & 1 & 0 & 15 \\
\hline S 10 & 0 & 1 & 0 & 1 & 1 & 1 & 1 & 1 & 1 & 0 & 0 & 1 & 0 & 1 & 1 & 1 & 1 & 0 & 0 & 1 & 13 \\
\hline S 11 & 0 & 1 & 1 & 0 & 0 & 1 & 0 & 0 & 1 & 0 & 1 & 1 & 0 & 0 & 1 & 1 & 1 & 0 & 1 & 0 & 10 \\
\hline S 12 & 0 & 1 & 1 & 0 & 0 & 0 & 0 & 0 & 0 & 1 & 0 & 1 & 0 & 1 & 0 & 1 & 0 & 1 & 0 & 0 & 7 \\
\hline S 13 & 0 & 1 & 0 & 0 & 0 & 0 & 1 & 1 & 1 & 1 & 1 & 0 & 0 & 1 & 1 & 0 & 0 & 1 & 1 & 0 & 10 \\
\hline S 14 & 0 & 1 & 1 & 0 & 1 & 0 & 1 & 0 & 1 & 1 & 1 & 1 & 1 & 0 & 0 & 1 & 1 & 1 & 0 & 0 & 12 \\
\hline S 15 & 0 & 0 & 0 & 0 & 0 & 1 & 0 & 0 & 0 & 1 & 1 & 1 & 1 & 0 & 1 & 1 & 0 & 1 & 0 & 1 & 9 \\
\hline S 16 & 0 & 0 & 0 & 1 & 1 & 1 & 1 & 1 & 1 & 1 & 1 & 0 & 1 & 1 & 1 & 1 & 0 & 1 & 1 & 0 & 14 \\
\hline S 17 & 0 & 0 & 0 & 0 & 0 & 0 & 1 & 1 & 1 & 0 & 0 & 1 & 0 & 1 & 1 & 1 & 0 & 1 & 0 & 0 & 8 \\
\hline S 18 & 0 & 1 & 1 & 1 & 1 & 1 & 1 & 1 & 1 & 1 & 1 & 1 & 1 & 1 & 1 & 1 & 1 & 1 & 0 & 1 & 18 \\
\hline S 19 & 1 & 1 & 1 & 1 & 1 & 1 & 1 & 1 & 0 & 1 & 1 & 1 & 0 & 1 & 1 & 1 & 0 & 1 & 1 & 0 & 16 \\
\hline S 20 & 1 & 1 & 0 & 0 & 0 & 1 & 0 & 1 & 1 & 1 & 0 & 0 & 1 & 1 & 1 & 1 & 0 & 0 & 0 & 0 & 10 \\
\hline
\end{tabular}




\begin{tabular}{lrrrrrrrrrrrrrrrrrrrrr} 
S 21 & 0 & 1 & 0 & 1 & 1 & 1 & 0 & 0 & 1 & 1 & 1 & 1 & 1 & 1 & 1 & 1 & 1 & 0 & 0 & 1 & 14 \\
S 22 & 1 & 1 & 0 & 0 & 1 & 1 & 1 & 1 & 1 & 1 & 1 & 1 & 1 & 1 & 1 & 1 & 1 & 1 & 1 & 1 & 18 \\
S 23 & 1 & 1 & 1 & 1 & 1 & 1 & 1 & 1 & 1 & 1 & 1 & 1 & 1 & 1 & 1 & 1 & 1 & 1 & 1 & 1 & 20 \\
S 24 & 1 & 1 & 1 & 1 & 1 & 1 & 1 & 0 & 1 & 1 & 1 & 0 & 1 & 1 & 1 & 1 & 1 & 1 & 1 & 1 & 18 \\
S 25 & 0 & 0 & 1 & 1 & 0 & 1 & 0 & 1 & 0 & 1 & 0 & 0 & 1 & 1 & 1 & 1 & 1 & 1 & 0 & 1 & 12 \\
S 26 & 0 & 1 & 0 & 1 & 1 & 1 & 1 & 1 & 1 & 1 & 0 & 1 & 1 & 1 & 1 & 1 & 0 & 0 & 1 & 0 & 14 \\
S 27 & 1 & 1 & 1 & 1 & 1 & 1 & 1 & 1 & 1 & 1 & 1 & 1 & 1 & 1 & 1 & 1 & 1 & 1 & 1 & 1 & 20 \\
S 28 & 1 & 1 & 1 & 1 & 1 & 1 & 1 & 1 & 1 & 1 & 1 & 1 & 1 & 1 & 1 & 1 & 1 & 1 & 1 & 1 & 20 \\
S 29 & 1 & 1 & 0 & 1 & 1 & 1 & 0 & 0 & 1 & 1 & 1 & 1 & 0 & 1 & 1 & 1 & 1 & 0 & 0 & 1 & 1 \\
S 30 & 0 & 1 & 1 & 1 & 1 & 1 & 1 & 1 & 1 & 1 & 1 & 1 & 1 & 1 & 1 & 1 & 1 & 1 & 1 & 1 & 1 \\
x & 0,50 & 0,77 & 0,5 & 0,73 & 0,70 & 0,73 & 0,63 & 0,60 & 0,87 & 0,83 & 0,67 & 0,67 & 0,70 & 0,90 & 0,73 & 0,90 & 0,67 & 0,73 & 0,63 & 0,57 & 14,07 \\
\hline
\end{tabular}

Note: The postest average of the experimental group is 14,07 over 20.

Source: Postest experimental group

Developed by: The author

With regard to the control group test, the data obtained were analyzed through statistical methods to get some denominations. The results are presented in table 5.

Table 5. Control group findings

\begin{tabular}{llrl}
\hline \multicolumn{1}{c}{ Denomination } & Value & \multicolumn{1}{c}{$\%$} & Observation \\
\hline Variance & 0,2242 & 22,42 & \\
Standard deviation & 0,4735 & 47,35 & \\
Variance coefficient & 0,4735 & 47,35 & \\
Correlation coefficient - Results & 0,0279 & 2,79 & Between pre and post-test \\
Correlation coefficient - Medians & 0,1705 & 17,05 & Between the medians \\
Correlation coefficient - Global & 0,1399 & 13,99 & Between the post-tests \\
\hline
\end{tabular}

Note: The correlation coefficient of the control group between the pre and the post-test is 2,79 over 100.

Source: Postest control group

Developed by: The author

This suggests that the correlation coefficient is 2,79 and thus the range of mastery of grammar tenses shows a low performance among the pre and post tests. The students didn't progress as much as required.

After examining the postest results of the experimental group, some statistical denominations were obtained to compare both groups. The findings are presented in table 6.

Table 6. Experimental group findings

\begin{tabular}{llll}
\hline \multicolumn{1}{c}{ Denomination } & Value & \multicolumn{1}{c}{$\%$} & Observation \\
\hline Variance & 0,2090 & 20,90 & \\
Standard deviation & 0,4572 & 45,72 & \\
Variance coefficient & 0,4572 & 45,72 & \\
Correlation coefficient - Results & 0,0461 & 4,61 Between pre and post-test \\
Correlation coefficient - Medians & 0,0491 & 4,91 Between the medians
\end{tabular}




\section{Correlation coefficient - Global $\quad 0,1399 \quad 13,99$ Between the post-tests}

Note: The correlation coefficient of the experimental group between the pre and the post-test is 4,61 over 100.

Source: Postest experimental group

Developed by: The author

Evidently, the range of the correlation coefficient goes up, being this 4,61. Consequently, the students who were given the treatment enhanced their mastery of grammar tenses obtaining a \%1.82 of improving over the control group.

Table 7. Pretests and postests total averages

\begin{tabular}{ll}
\hline Total Averages & \\
\hline Pre test control group & 13,11 \\
Pre test experimental group & 13,23 \\
Postest control group & 13,23 \\
Postest experimental group & 14,07 \\
\hline
\end{tabular}

Source: Pretests and postests of the control and experimental groups.

Developed by: The author.

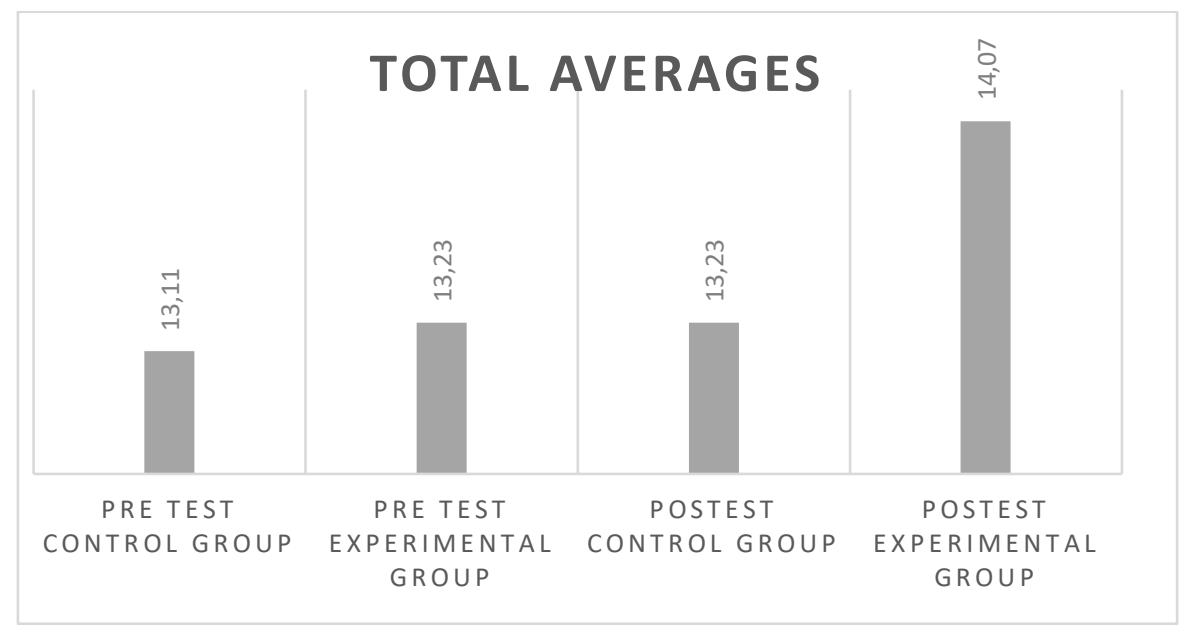

Figure 1. Total Average of both groups tests Developed by: The author

Being the pretest and posttest analyzed, the results were placed into a total averages table. In the final analysis, making a comparison, it is established that the control and experimental group started with a similar average of the test results. On the other hand, there is an improvement in both groups after implementing the treatment with the experimental group. However, it is important to highlight that the posttest average of the experimental group had increased in a range of 0,84 over the postest of the control group.

Therefore, it is notable that the implementation of graphic organizers can help students to improve the knowledge of grammar skills over grammatical teaching with excessive amounts of texts. 


\section{Conclusiones.}

- The post-test findings demonstrated that the competence of the experimental group had enhanced after implementing graphic organizers. With these tools implemented, the level of the acquisition was higher than using isolated texts or bits of information.

- Students were able to structure different types of graphic organizers that helped them to clear up their ideas and to establish better relationships between graphical and cognitive demands.

- Graphic organizers are effective tools in the process of organizing and constructing knowledge. They reduced the anxiety and pressure students felt when processing vast amounts of information. Besides, the grammatical information represented visually could help students to remember all the patterns, rules, and restrictions easily. To sum up, graphic organizers will contribute positively to master grammar patterns.

\section{Referencias bibliográficas.}

Apuke, O. (2017). Quantitative Research Methods: A Synopsis Approach. Arabian Journal of Business and Management Review, 6(11), 40-47. https://doi.org/10.12816/0040336

Ciascai, L. (2009). Using Graphic Organizers in Intercultural Education. Acta Didáctica Napocensia, 2(1), 10-18.

Chen, H. \& Jones, P. (2012). Understanding metalinguistic development in beginning writers. Journal of Applied Linguistics and Professional Practice, 9 (1), 81-104.

Dahbi, M. (2014). Implementing Graphic Organisers to Teach Grammar to Moroccan Second Year Baccalaureate Students: an Action Research Project. IOSR Journal of Research and Method in Education, 4(5), 37-42. https://bit.ly/3cFrsyB

Delrose, L. (2011). Investigating the use of graphic organizers for writing. LSU Master's Thesis. 2537. https://bit.ly/37CKxyS

EF EPI. (2019). Índice EF de nivel de inglés Una clasificación de 100 países y regiones en función de su nivel de inglés. EF. https://bit.ly/30MyT1b

EF EPI, E., \& Howard, P. (2005). Graphic organizers: Power tools for teach-ing students with learning disabilities. Graphic Organizers and Learning Disabilities 1, 1-5.

Foppoli, J. (2018). Is Grammar Really Important for a Second Language Learner? Eslbase.com.

Garrido, C., \& Rosado, C. (2012). Errors in the use of English tenses. Íkala, revista de lenguaje y cultura, 17(3), 285-296. 
Jean, G., \& Simard, D. (2011). Grammar Teaching and Learning in L2: Necessary, but Boring? Foreign Language Annals, 44(3), 467-494. https://doi.org/10.1111/j.1944-9720.2011.01143.x

Kansizoğlu, H. (2017). The Effect of Graphic Organizers on Language Teaching and Learning Areas: A Meta-Analysis Study. TED E ĞITIM VE BILIM, 42(191), 139164. https://doi.org/10.15390/eb.2017.6777

Kelly, Andrew. (2018). A place for teaching grammar? Analysing challenges in developing grammatical knowledge for ESL and non-traditional students at university. Journal of Language Teaching and Learning. 8. 71-85.

Mammadova, T. (2019). Teaching Grammar to a Grammar-Free Generation (Cambridge Scholar Publishing ed.).

Mart, Ç. T. (2013). Teaching grammar in context: Why and how? Theory and Practice in Language Studies, 3(1), 124-129. https://doi.org/10.4304/tpls.3.1.124-129

Nassaji, H. (2015). Qualitative and descriptive research: Data type versus data analysis. Language Teaching $\quad$ Research, 19(2), 129-132. https://doi.org/10.1177/1362168815572747

Paredes, R., Henríquez, E., Zurita, R., Pinos, V., Apolinario, O., \& Campoverde, M. (2018). New Curriculum in Ecuador. Journal of Chemical Information and Modeling (Vol. 1, p. 75). https://doi.org/10.1017/CBO9781107415324.004

Rahman, M., \& Ali, M. (2015b). Problems in Mastering English Tense and Aspect and the Role of the Practitioners. IOSR Journal Of Humanities And Social Science, 20(4), 131-135. https://doi.org/10.9790/0837-2041131135

Thyer, B. (2012). Quasi-Experimental Research Designs. Oxford Scholarship, 1-216. https://doi.org/10.1093/acprof:oso/9780195387384.001.0001

Varade, G. (2017). Make grammar fun using graphic organizers. Scholarly Research Journal, 4, 4530-4533.

Vargas, J., \& Zúñiga, R. (2018). Graphic organizers as a teaching strategy for improved comprehension of argumentative texts in English. Actualidades Investigativas en Educación, 18(2), 1-22. https://doi.org/10.15517/aie.v18i2.33028

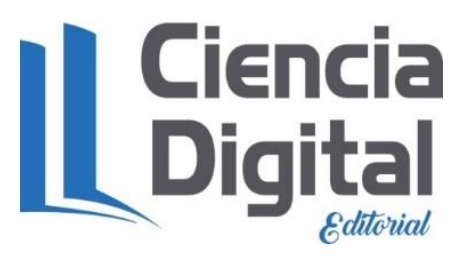




\section{PARA CITAR EL ARTÍCULO INDEXADO.}

Medina Rea, J. M. (2021). Graphic organizers to empower the teaching-learning process of grammar tenses in higher education. ConcienciaDigital, 4(3), 54-67. https://doi.org/10.33262/concienciadigital.v4i3.1764

\section{Ciencia \\ LDigital}

El artículo que se publica es de exclusiva responsabilidad de los autores y no necesariamente reflejan el pensamiento de la Revista Ciencia Digital.

El artículo queda en propiedad de la revista y, por tanto, su publicación parcial y/o total en otro medio tiene que ser autorizado por el director de la Revista Ciencia Digital.
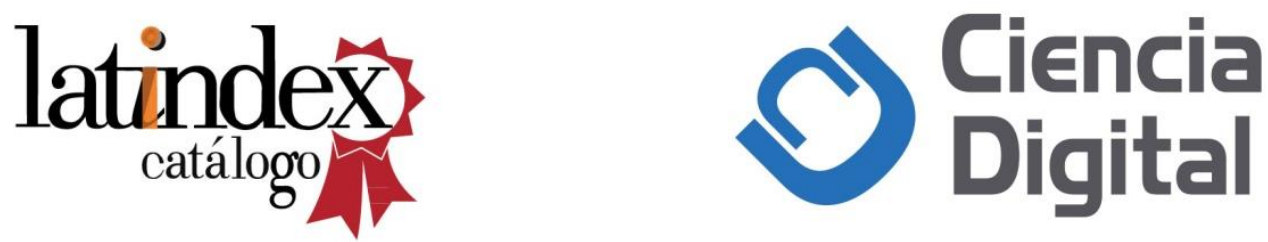